\title{
In vivo antioxidant activity of Ethanolic extract from root of Smilax zeylanica on Aluminium Chloride Induced oxidative stress in Wistar rats
}

\author{
B. Sabari Senthil*, V.K. Kalaichelvan and A. Kottai Muthu \\ Department of Pharmacy, Annamalai University, Annamalai Nagar - 608 002. Tamil Nadu, India
}

\begin{abstract}
Objective: The objective of the present study was to investigate the Evaluation of In vivo antioxidant activity of Ethanolic extract of root of Smilax zeylanica(EESZ) on Aluminium Chloride Induced apoptosis suppressing oxidative stress in Wistar rats. Materials and Methods: The ethanolic extract from the roots of $S$. china by hot continuous percolation method. The rats were divided into 5 groups and each group consists of 6 animals. Rats were treated with EESC for 150 and $300 \mathrm{mg} / \mathrm{kg}$ of body weight and piracetam, $0.5 \mathrm{mg} / \mathrm{kg}$ of body weight for 14 successive days after inducing oxidative stress with aluminium chloride (100 mg/ kg of body weight) for 60 days. The lipid peroxidation level (TBARS) and antioxidant activities like Superoxide dismutase (SOD), Catalase (CAT) and reduced Glutathione (GSH) were estimated in rats. Results: $\mathrm{AlCl}_{3}$ induced rats showed increased the TBARS and decreased the antioxidant enzymes like Superoxide dismutase (SOD), Catalase (CAT) and reduced Glutathione (GSH) when compared with the control group. The EESZ at higher dose 300 mg/ kg of body weight animals were significantly $(\mathrm{P}<0.001)$ reduced the TBARS and increased the anti oxidant enzymes Superoxide dismutase (SOD), Catalase (CAT) and reduced Glutathione (GSH) when compared with the $\mathrm{AlCl}_{3}$ treated group Conclusion: Findings of the present study revealed that Ethanolic extract from roots of Smilax zeylanica may be used as a significant source of natural antioxidant, which might be helpful in preventing the progress of various oxidative stresses.
\end{abstract}

Keywords: S. zeylanica, antioxidant, ethanolic extract, TBARS, rats.

Article Info: Received 13 Oct 2018; Review Completed 24 Nov 2018; Accepted 27 Nov 2018; Available online 15 Dec 2018

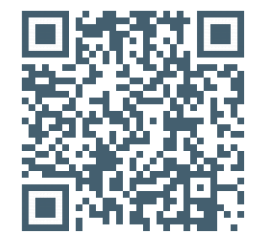

\section{Cite this article as:}

Senthil BS, Kalaichelvan VK, Kottai Muthu A, In vivo antioxidant activity of Ethanolic extract from root of Smilax zeylanica on Aluminium Chloride Induced oxidative stress in Wistar rats, Journal of Drug Delivery and Therapeutics. 2018; 8(6-s):48-52 DOI: http://dx.doi.org/10.22270/jddt.v8i6-s.2078

B. Sabari Senthil, M. Pharm., Department of Pharmacy, Annamalai University, Annamalai Nagar-608002, India

\section{INTRODUCTION}

Reactive oxygen and nitrogen species play key roles in normal physiological process, including cellular life/death process, protection from pathogens, various cellular signaling pathways, and regulation of vascular tone ${ }^{1}$. Oxidative stress is caused by an insufficient capacity of biological systems to neutralize excessive free radical production, which can contribute to cardiovascular disease $^{2}$, neurodegerative disease and age-related cognitive decline ${ }^{3}$,as well as immune system dysfunction ${ }^{4}$. Considerable evidence have accumulated to implicate cellular damage arising from reactive oxygen species (ROS), at least in part, in the etiology and pathophysiology of human diseases such as neurodegenerative disorders (e.g. Alzheimer disease, Parkinson disease, multiple sclerosis, Down's syndrome), inflammation, viral infections, autoimmune pathologies, and digestive system disorders such as gastrointestinal inflammation and ulcer ${ }^{5}$.

The roots of Smilax zeylanica is belong to the Smilacaceae family. It is commonly distributed in the forest and hills of south India and found in tropical and subtropical hills from
Himalayan region in the north to Kerala in south. It is widely in hilly region of Karnataka, Kerala and Tamil Nadu between altitudes of 500-1800 meter. S. zeylanica is used ethnomedicinally for the treatment of different conditions such as abscesses, boils, dysentery, psoriasis, rheumatism, skin diseases, swellings, toothache and venereal diseases 6 10. This plant is shown to exhibit several bioactivities such as antimicrobial and analgesic ${ }^{11,12}$, antioxidant ${ }^{12,13}$, cytotoxic ${ }^{13}$, immunomodulatory and antiarthritic ${ }^{14}$, anthelmintic ${ }^{15}$, antipyretic ${ }^{16}$ anticonvulsant ${ }^{16}$, antidiabetic ${ }^{17}$, cytoprotective ${ }^{18}$, hepatoprotective ${ }^{19}$, antiinflammatory 20 antiepileptic ${ }^{21}$, pesticidal $^{22}$, thrombolytic ${ }^{23}$, and antidepressant ${ }^{24}$ activities. Therefore, the present investigation focused to evaluate the invivo antioxidant potential of ethanolic extract of roots of Smilax zeylanica in different screening methods.

\section{MATERIALS AND METHODS}

\section{Collection and Identification of Plant materials}

The roots of Smilax zeylanica were collected form Kulithalai,Kanyakumari District, Tamil Nadu, India. 
Taxonomic identification was made from Botanical Survey of Medical Plants Unit Siddha, Government of India. Palayamkottai. The roots of Smilax zeylanica were dried under shade, segregated, pulverized by a mechanical grinder and passed through a 40 mesh sieve.

\section{Preparation of Extracts}

The above powdered plant materials were consecutively extracted with pet. ether $\left(40-60^{\circ} \mathrm{C}\right)$ by hot continuous percolation method in Soxhlet apparatus ${ }^{25}$ for one day. The marc was dried out and extracted with chloroform and then marc was extracted with ethyl acetate $\left(76-78^{\circ} \mathrm{C}\right)$ for one day, then this marc was dried out after that it was extracted with ethanol for one day and then marc was extracted with water. All the three extracts were concentrated by utilizing a rotary evaporator and undergone to freeze drying using a lyophilizer until dry powder was acquired. The ethanolic extract gave more yield and more phytoconstituents were present. So the ethanolic extract of Smilax zeylanica was selected for the further investigation.

\section{Evaluation of In-vivo antioxidant activity:}

\section{Experimental}

Both the genders of Wister rats with 8 weeks weighed between 150 and $200 \mathrm{~g}$ of body weight was used for the present study. Rats were acclimatized for experimental conditions for about two weeks. The rats housed in plastic cages at $25^{\circ} \mathrm{C}$ with relative humidity of $70 \%$ under $12 / 12$ hours day/ night cycle. Rats were fed with food and water ad libitum. The experiments were approved as per the strategy of CPCSEA, New Delhi, India and approved by the Annamalai University IAEC (Approved number: AU/IAEC/1199/1/18). Animals were grouped randomly into five different groups with six rats in each group:

Group 1: Control - received saline (5 ml/ kg p.o.).

Group 2: Negative control group i.e received aluminium chloride at dose of $100 \mathrm{mg} / \mathrm{kg}$ of body weight p.o.

Group 3: Aluminium chloride + Ethanolic extract of Smilax zeylanica $(150 \mathrm{mg} / \mathrm{kg}$ of body weight p.o.)

Group 4: Aluminium chloride + Ethanolic extract of Smilax zeylanica $(300 \mathrm{mg} / \mathrm{kg}$ of body weight p.o.)
Groups 5: Aluminium chloride + piracetam $(0.5 \mathrm{mg} / \mathrm{kg}$ body weight p.o.)

Oxidative stress was induced to the all the rats, expect in the group I, by Aluminium Chloride at a dose of $100 \mathrm{mg} /$ $\mathrm{kg} /$ body weight for 60 days through oral gavage. From $61^{\text {st }}$ day onwards the group 3 and 4 animals were treated with the ethanolic extract of Smilax zeylanica for 30 days. At the end of the experimental period, the rats were sacrificed by cervical decapitation after overnight fasting. Dissected hippocampus, cortex and cerebellum were grinded in $10 \mathrm{mM}$ Tris $/ \mathrm{HCl}(\mathrm{pH} \mathrm{7.0)}$ containing $10 \mu \mathrm{l} / \mathrm{ml}$ protease inhibitor and were centrifuged to separate the nuclear debris. Supernatant 1 (S1) was collected and used for quantification of the levels of thiobarbituric acid reactive substances (TBARS) ${ }^{26}$ and the remaining pellet was further centrifuged to get the post-mitochondrial fraction, which was used for the assay of antioxidants like used for the estimation of Superoxide dismutase (SOD) ${ }^{27}$, Catalase (CAT) ${ }^{28}$ and reduced Glutathione (GSH) ${ }^{29}$.

\section{Statistical analysis}

Data were presented as mean \pm SEM. One-way ANOVA using Tukey's employed for post hoc test for multiple comparisons. The value of $\mathrm{P}<0.05$ was considered statistically significant.

\section{RESULTS AND DISCUSSION}

\section{Effect of ethanolic extracts of roots of Smilax zeylanica on Brain tissue TBARS levels in $\mathrm{AlCl}_{3}$ induced rats}

Effect of ethanolic extracts of roots of Smilax zeylanica on brain tissues like, hippocampus cortex and cerebellum TBARS level results is shown in Tables 1 and Fig .1.. The activities of TBARS in the tissue like hippocampus cortex and cerebellum, significantly $(\mathrm{P}<0.001)$ increased in rats fed with AlCl3-treated animals (group II) than control group animals.AlCl3 treatment significantly increased TBARS levels, a sensitive marker of the lipid peroxidation process. Previous reports showed the Al exposure could elevate the free radical generation and oxidative damage in specific areas of brain including cerebral cortex ${ }^{30,31}$, hippocampus $\quad{ }^{30}$,cerebellum $\quad 31,32$.Administration of ethanolic extract extracts of roots of Smilax zeylanica on brain tissues like, hippocampus cortex and cerebellum TBARS levels were significantly reduced when compared to $\mathrm{AlCl}_{3}$-treated animals.

Table 1: Effect of ethanolic extracts of Smilax zeylanica on tissues TBARS in $\mathrm{AlCl}_{3}$ induced rats

\begin{tabular}{|l|c|c|c|}
\hline \multirow{2}{*}{ Groups } & \multicolumn{3}{|c|}{ TBARS (n mol of MDA formed/g tissue) } \\
\cline { 2 - 4 } & Hippocampus & Cortex & Cerebellum \\
\hline Group I & $2.36 \pm 0.13^{\mathrm{a}, 1}$ & $6.75 \pm 0.22^{\mathrm{a}, 1}$ & $2.23 \pm 0.14^{\mathrm{a}, 1}$ \\
\hline Group II & $9.56 \pm 0.15^{\mathrm{a}, 1,2}$ & $14.66 \pm 0.27^{\mathrm{b}, 1,2}$ & $6.23 \pm 0.18^{\mathrm{b}, 1,2}$ \\
\hline Group III & $7.45 \pm 0.16^{\mathrm{a}, 1,2}$ & $12.55 \pm 0.16^{\mathrm{b}, 1,2}$ & $4.97 \pm 0.16^{\mathrm{b}, 1,2}$ \\
\hline Group IV & $3.65 \pm 0.08^{\mathrm{b}, 1,2}$ & $7.12 \pm 0.11^{\mathrm{a}, 1,2}$ & $2.56 \pm 0.37^{\mathrm{b}, 1,2}$ \\
\hline Group V & $3.18 \pm 0.19^{\mathrm{c},, 2}$ & $6.89 \pm 0.19^{\mathrm{c}, 2}, 2$ & $2.42 \pm 0.13^{\mathrm{c}, 2}$ \\
\hline
\end{tabular}

Values are expressed as mean \pm SEM of 6 animals. Statistical significance tested by one way ANOVA, followed by Tukey's " $\mathrm{t}$ " test. a $\mathrm{P}<0.05 ; \mathrm{b}-\mathrm{P}<0.01 ; \mathrm{c}-\mathrm{P}<0.005 ; 1$ - compared with group I; 2 - compared with group V. Group I: Control - received saline (5 ml/ kg p.o.).Group II: Negative control group i.e received aluminium chloride at dose of $100 \mathrm{mg} / \mathrm{kg}$ of body weight p.o.,Group III: Aluminium chloride + Ethanolic extract of Smilax zeylanica $(150 \mathrm{mg} / \mathrm{kg}$ of body weight p.o.),Group IV: Aluminium chloride + Ethanolic extract of Smilax zeylanica (300 mg/ kg of body weight p.o.),Groups V: Aluminium chloride + piracetam (0.5mg/ kg body weight p.o.) 


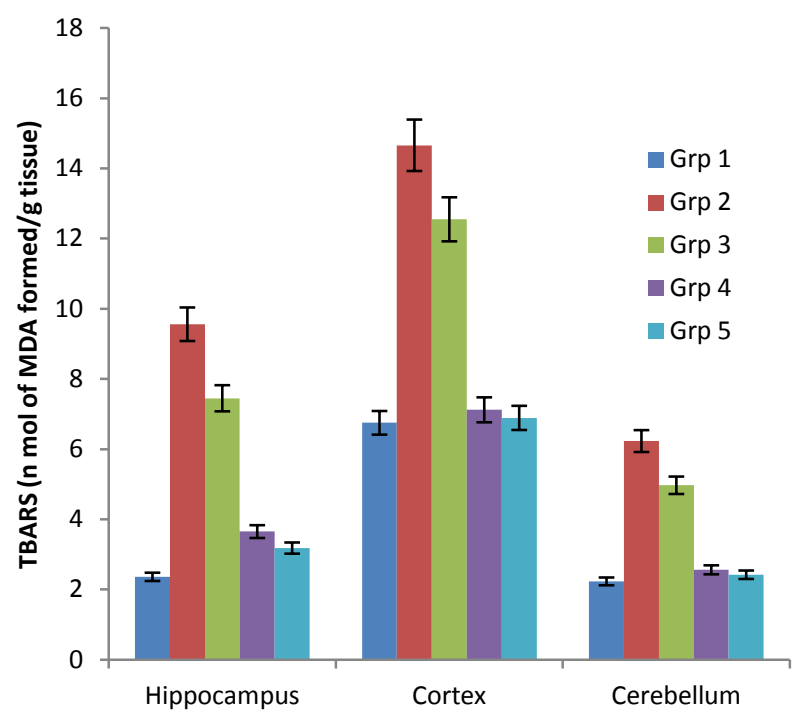

Figure 1: Effect of ethanolic extracts of Smilax china on tissues TBARS in $\mathrm{AlCl}_{3}$ induced rats
Effect of ethanolic extracts of roots of Smilax zeylanica on Brain tissue enzymatic antioxidants in $\mathrm{AlCl}_{3}$ induced rats

Effect of ethanolic extracts of roots of Smilax zeylanica on brain tissues like, hippocampus cortex and cerebellum SOD and CAT level results is shown in Tables 2 \& 3 and Fig. 2 \& 3 respectively. The activities of SOD and CAT in the tissue like hippocampus cortex and cerebellum, significantly $(\mathrm{P}<0.001)$ lowered in rats fed with $\mathrm{AlCl} 3$-treated animals (group II) than control group animals. Metals such as copper, iron, cadmium, arsenic, mercury, nickel and Al induced their toxic effects due to their ability to transfer electrons and free radicals production. Chronic exposure of $\mathrm{Al}$ could leads to the disruptions of mineral balance by replacing iron and magnesium ions ${ }^{33}$. Previous reports showed the Al exposure could elevate the free radical generation and oxidative damage in specific areas of brain including cerebral cortex, hippocampus, cerebellum. Administration of ethanolic extract extracts of roots of Smilax zeylanica on brain tissues like, hippocampus cortex and cerebellum SOD and CAT levels were significantly increased when compared to $\mathrm{AlCl}_{3}$-treated animals.

Table 2: Effect of ethanolic extracts of Smilax zeylanica on tissues superoxide dismutase in $\mathrm{AlCl}_{3}$ induced rats

\begin{tabular}{|l|c|c|c|}
\hline \multirow{2}{*}{ Groups } & \multicolumn{3}{|c|}{ SOD (unit min/mg protein) } \\
\cline { 2 - 4 } & Hippocampus & Cortex & Cerebellum \\
\hline Group I & $4.66 \pm 0.22^{\mathrm{a}, 1}$ & $3.65 \pm 0.18^{\mathrm{a}, 1}$ & $2.87 \pm 0.12^{\mathrm{a}, 1}$ \\
\hline Group II & $2.11 \pm 0.17^{\mathrm{b}, 1,2}$ & $1.96 \pm 0.23^{\mathrm{a}, 1,2}$ & $1.67 \pm 0.20^{\mathrm{a}, 1,2}$ \\
\hline Group III & $2.92 \pm 0.16^{\mathrm{b}, 1,2}$ & $2.34 \pm 0.18^{\mathrm{b}, 1,2}$ & $1.98 \pm 0.16^{\mathrm{b}, 1,2}$ \\
\hline Group IV & $3.92 \pm 0.22^{\mathrm{a}, 1,2}$ & $3.68 \pm 0.19^{\mathrm{b}, 1,2}$ & $2.45 \pm 0.22^{\mathrm{b}, 1,2}$ \\
\hline Group V & $3.86 \pm 0.18^{\mathrm{c}, 2}$ & $3.45 \pm 0.14^{\mathrm{c}, 2}$ & $2.40 \pm 0.18^{\mathrm{b}, 2}$ \\
\hline
\end{tabular}

Values are expressed as mean \pm SEM of 6 animals. Statistical significance tested by one way ANOVA, followed by Tukey's " $\mathrm{t}$ " test. a $\mathrm{P}<0.05 ; \mathrm{b}-\mathrm{P}<0.01 ; \mathrm{c}-\mathrm{P}<0.005 ; 1$ - compared with group I; 2 - compared with group V.

Table 3: Effect of ethanolic extracts of Smilax china on tissues catalase $\mathrm{AlCl}_{3}$ induced rats

\begin{tabular}{|l|c|c|c|}
\hline \multirow{2}{*}{ Groups } & \multicolumn{3}{|c|}{ CAT $\left(\boldsymbol{\mu}\right.$ moles of $\mathrm{H}_{2} \mathrm{O}_{2}$, consumed min/mg protein) } \\
\cline { 2 - 4 } & Hippocampus & Cortex & Cerebellum \\
\hline Group I & $3.52 \pm 0.12^{\mathrm{a}, 1}$ & $3.23 \pm 0.18^{\mathrm{a}, 1}$ & $2.12 \pm 0.18^{\mathrm{a}, 1}$ \\
\hline Group II & $1.78 \pm 0.12^{\mathrm{b}, 1,2}$ & $1.48 \pm 0.16^{\mathrm{a}, 1,2}$ & $1.08 \pm 0.16^{\mathrm{b}, 1,2}$ \\
\hline Group III & $2.02 \pm 0.14^{\mathrm{a}, 1,2}$ & $2.14 \pm 0.12^{\mathrm{b}, 1,2}$ & $1.34 \pm 0.13^{\mathrm{b}, 1,2}$ \\
\hline Group IV & $2.98 \pm 0.14^{\mathrm{b}, 1,2}$ & $3.02 \pm 0 . .18^{\mathrm{a}, 1,2}$ & $2.03 \pm 0 . .12^{\mathrm{b}, 1,2}$ \\
\hline Group V & $2.68 \pm 0.20^{\mathrm{c}, 2}$ & $2.98 \pm 0.22^{\mathrm{c}, 2}$ & $2.08 \pm 0.17^{\mathrm{c}, 2}$ \\
\hline
\end{tabular}

Values are expressed as mean \pm SEM of 6 animals. Statistical significance tested by one way ANOVA, followed by Tukey's " $\mathrm{t}$ " test. a $\mathrm{P}<0.05 ; \mathrm{b}-\mathrm{P}<0.01 ; \mathrm{c}-\mathrm{P}<0.005 ; 1$ - compared with group I; 2 - compared with group V.

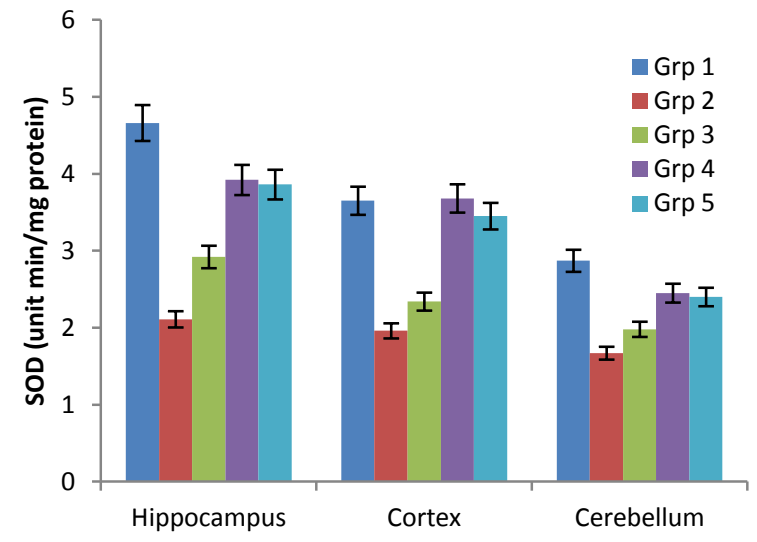

Figure 2: Effect of ethanolic extracts of Smilax china on tissues superoxide dismutase in $\mathrm{AlCl}_{3}$ induced rats

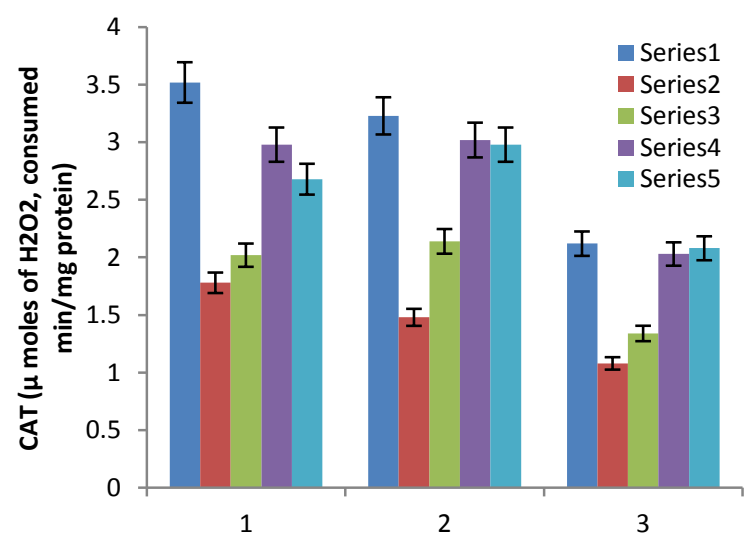

Figure 3: Effect of ethanolic extracts of Smilax china on tissues $\mathrm{CAT}$ in $\mathrm{AlCl}_{3}$ induced rats 
Effect of ethanolic extracts of Smilax zeylanica on tissues glutathione $\mathrm{AlCl} 3$ induced rats

Effects of ethanolic extracts of Smilax zeylanica on brain tissues like, hippocampus cortex and cerebellum glutathione $\mathrm{AlCl}_{3}$ induced rats results are shown in Table 4. Glutathione (GSH), a tripeptide which is present in all the cells is an important antioxidant. The activities of activities of glutathione concentration in the tissue like hippocampus cortex and cerebellum, significantly $(\mathrm{P}<0.001)$ lowered in rats fed with $\mathrm{AlCl} 3$-treated animals (group II) than control group animals. Metals such as copper, iron, cadmium, arsenic, mercury, nickel and Al induced their toxic effects due to their ability to transfer electrons and free radicals production. Chronic exposure of Al could leads to the disruptions of mineral balance by replacing iron and magnesium ions ${ }^{33}$. $\mathrm{AlCl} 3$ exposure was accompanied by decrease in the levels of GSH and the activities of GPx and catalase in brains of rats ${ }^{34}$ and mice ${ }^{35}$ Administration of ethanolic extract extracts of roots of Smilax zeylanica $(300 \mathrm{mg} / \mathrm{kg}$ body weight) on brain tissues like, hippocampus cortex and cerebellum GSH levels were significantly increased when compared to $\mathrm{AlCl}_{3}$-treated animals

Table 4: Effect ethanolic extracts of Smilax zeylanica on tissues glutathione $\mathrm{AlCl}_{3}$ induced rats

\begin{tabular}{|l|c|c|c|}
\hline \multirow{2}{*}{ Groups } & \multicolumn{3}{|c|}{ Glutathione (mg/g tissue) } \\
\cline { 2 - 4 } & Hippocampus & Cortex & Cerebellum \\
\hline Group I & $19.52 \pm 0.33^{\mathrm{a}, 1}$ & $22.44 \pm 0.42^{\mathrm{a}, 1}$ & $15.34 \pm 0.32^{\mathrm{a}, 1}$ \\
\hline Group II & $9.44 \pm 0.22^{\mathrm{b}, 1,2}$ & $12.12 \pm 0.32^{\mathrm{a}, 1,2}$ & $6.78 \pm 0.24^{\mathrm{b}, 1,2}$ \\
\hline Group III & $13.53 \pm 0.12^{\mathrm{a}, 1,2}$ & $14.98 \pm 0.45^{\mathrm{b}, 1,2}$ & $8.87 \pm 0.15^{\mathrm{a}, 1,2}$ \\
\hline Group IV & $18.76 \pm 0.16^{\mathrm{b}, 1,2}$ & $20.08 \pm 0.21^{\mathrm{b}, 1,2}$ & $14.32 \pm 0.18^{\mathrm{b}, 1,2}$ \\
\hline Group V & $17.22 \pm 0.22^{\mathrm{c}, 2}$ & $19.45 \pm 0.38^{\mathrm{c}, 2}$ & $13.56 \pm 0.18^{\mathrm{c}, 2}$ \\
\hline
\end{tabular}

Values are expressed as mean \pm SEM of 6 animals. Statistical significance tested by one way ANOVA, followed by Tukey's " $\mathrm{t}$ " test. a $\mathrm{P}<0.05 ; \mathrm{b}-\mathrm{P}<0.01 ; \mathrm{c}-\mathrm{P}<0.005 ; 1$ - compared with group I; 2 - compared with group V.

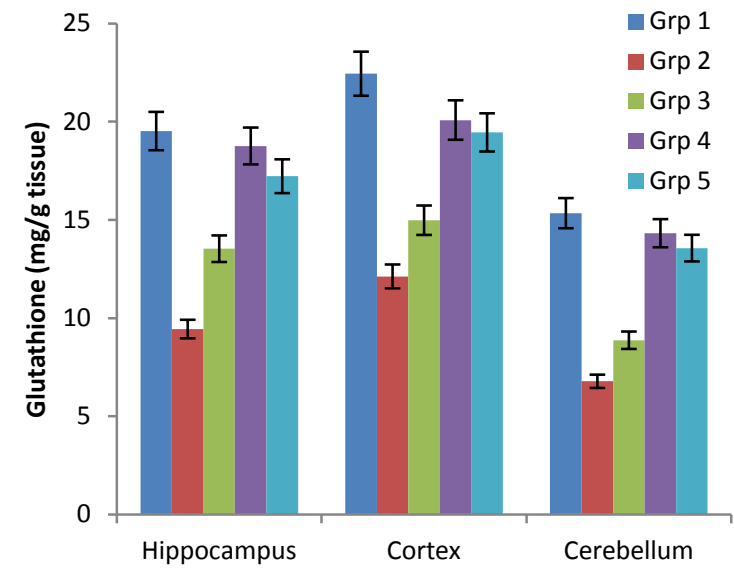

Figure 4: Effect ethanolic extracts of Smilax china on tissues glutathione $\mathrm{AlCl}_{3}$ induced rats

\section{CONCLUSION}

$\mathrm{AlCl}_{3}$ is induced the oxidative stress in rats were significantly increased TBARS and reduced antioxidant enzymes. On the basis of the results obtained in the present study, we conclude that the ethanolic extract from roots of Smilax zeylanica had significant in vivo antioxidant and lipid peroxidation activity when compared with $\mathrm{AlCl}_{3}$ treated rats. The phytoconstituents may be responsible for the inhibition of lipid peroxidation and enhance the antioxidant activities.

\section{REFERENCES}

1. Valko,M ; Leibfritz, D; Moncol, J; Cronin, M.T; Mazur, M; Telser, J. Free radicals and antioxidants in normal physiological functions and human disease. Int. J. Biochem. Cell Biol. 2007; 39:44-84.

2. Victor, V.M; Rocha, M. targeting antioxidants to mitochondria: a potential new therapeutic strategy for cardiovascular diseases. Curr. Pharm. Des. 2007; 13:845863.

3. Swerdlow, R. H. Treating neurodegeneration by modifying mitochondria: potential solutions to a "complex" problem. Antioxid. Redox signal. 2007; 9:1591-1603.
4. Larbi, A; Kempf, J; Pawelec, G. Oxidative stress modulation and T cell activation. Exp. Gerontol. 2007; 42:852-858.

5. Repetto MG, Llesuy SF. Antioxidant properties of natural compounds used in popular medicine for gastric ulcers. Braz. J. Med. Biol. Res. 2002; 35(35):523-534

6. Shetty BV, Kaveriappa KM, Bhat GK. Plant resources of Western Ghats and lowlands of Dakshina Kannada and Udupi districts, Pilikula Nisarga Dhama Society, Mangalore, India, 2002; 58: 211.

7. Khare CP. Indian medicinal plants: An illustrated dictionary, Springer-Verlag Berlin/Heidelberg, 2007; 609.

8. Madhavan V, Hemalatha HT, Gurudeva MR, Yoganarasimhan SN. Pharmacognostical studies on the rhizome and roots of Smilax zeylanica Linn. - A potential alternate source for the Ayurvedic drug Chopachinee, Indian J Nat Prod Resour, 2010; 1(3):328-337.

9. Gritto MJ, Aslam A, Nandagopalan V. Ethnomedicinal survey of threatened plants in Pachamalai hills, Tiruchirapalli district, Tamil Nadu, India, Int J Res Ayurveda Pharm,2012; 3(6):844-846.

10. Luitel DR, Rokaya MB, Timsina B, Munzbergova Z. Medicinal plants used by the Tamang community in the Makawanpur district of central Nepal, J Ethnobiol Ethnomed, 2014; 10:5.

11. Hossain AM, Saha S, Asadujjaman M, Kahan AS.Analgesic, antioxidant and antibacterial activity of Smilax zeylanica Linn. (family-Smilacaceae), Pharmacologyonline, 2013; 244-250.

12. Dhanya Shree VS, Arbin Ayesha, Saema Noorain GK, Sahana BK, Prashith Kekuda TR. Preliminary phytochemical analysis, antimicrobial and antioxidant activity of Smilax zeylanica L. (Smilacaceae) Journal of Drug Delivery \& Therapeutics, 2018; 8(4):237-243.

13. Uddin MN, Ahmed T, Pathan S, Al-Amin MM, Rana MS. Antioxidant and cytotoxic activity of stems of Smilax zeylanica in vitro, J Basic Clin Physiol Pharmacol,2015; 26(5):453-463.

14. Babu VP, Ashwini T, Krishna VM, Raju GM Immunomodulatory and antiarthritic activities of Smilax zeylanica, Int J Phytomed, 2017; 8:123-131.

15. Jena PK, Nayak BS, Dinda SC, Ellaiah P. Investigation on phytochemicals, anthelmintic and analgesic activities of Smilax zeylanica Linn. leafy extracts, Asian J Chem, 2011; 23(10):4307-4310.

16. Jena PK, Dinda SC, Ellaiah P. Phytochemical investigation and simultaneous study on antipyretic, anticonvulsant activity of different leafy extracts of Smilax zeylanica Linn, Orient Pharm Exp Med, 2012;12:123-127.

17. Jena PK, Dinda SC, Ellaiah P. Antidiabetic activity of various leafy extracts of Smilax zeylanica Linn in streptozotocin 
induced diabetic rats, Asian J Chem, 2012; 24(10):48254826.

18. Rajesh V, Perumal P. Cytoprotective effect of Smilax zeylanica Linn. leaves against Benzo[a]pyrene induced lung cancer with reference to lipid peroxidation and antioxidant system in Swiss albino mice, Orient Pharm Exp Med, 2013; 13:267-277.

19. Murali A, Ashok P, Madhavan V. Study of hepatoprotective activity of methanol extract of Smilax zeylanica L. leaf against carbontetrachloride induced hepatic damage in rats, MSRUAS-SAS Tech Journal, 2014;13(2):25-28.

20. Nithyamala I, Ayyasamy S, Pitchiahkumar M, Kumar A, Velapandian V. Evaluation of analgesic and antiinflammatory activity of Siddha drug Karuvilanchi ver choornam (roots powder of Smilax zeylanica Linn) in rodents, IOSR Journal of Pharmacy and Biological Sciences, 2013; 6(1):6-11.

21. Madhavan V, Hemalatha HT, Murali A, Yoganarasimhan SN. Antiepileptic activity of alcohol and aqueous extracts of roots and rhizomes of Smilax zeylanica Linn, Pharmacologyonline, 2008; 3:263-272.

22. Bari MA, Islam W, Khan AR. Pesticidal activity of Smilax zeylanica L. extracts on Cryptolestes pusillus (Schon.) (Coleoptera: Cucujidae), Journal of Bangladesh Academy of Sciences, 2010; 34(2):205-208.

23. Hossen MSM, Khan IN, Sarkar MMI, Jahid MA. Assessment of thrombolytic activity of five Bangladeshi medicinal plants: Potential source for thrombolytic compounds, International Blood Research and Reviews, 2014; 2(6):262269.

24. Ahemad RS, Venkataraman S, Ahmad F, Ibrahim M. Antidepressant-like activity of Smilax zeylanica Linn in behavioral despair tests in mice, European Journal of Pharmaceutical and Medical Research,2016;3(12): 335341.
25. Harborne J.B. Phytochemical methods 11 Edn. In Chapman \&, Hall. New York: 1984; 4-5.

26. Nichans WH, Samulelson B., Formation of malondialdehyde from phospholipid arachidonate during microsomal lipid peroxidation. Eur J Biochem, 1968; 6:126-30.

27. Kakkar P, Das B, Visvanathan PN., A modified spectrophotometric assay of SOD. Indian J Biochem Biophys, 1984; 21:130-2.

28. Sinha AK, Colorimetric assay of catalase, Anal. Biochem, 1972; 47:389.

29. Ellman GL., Tissue sulfhydroyl groups. Arch.Biochem.Biophy, 1959; 82:70.

30. Abd-Elghaffar S.K., El-Sokkary G.H., Sharkawy A.A., Aluminum-induced neurotoxicity and oxidative damage in rabbits: protective effect of melatonin. Neuro. Endocrinol. Lett. 2005; 26:609-616.

31. Nehru, B., Bhalla, P., Garg, A., Further evidence of centrophenoxine mediated protection in aluminium exposed rats by biochemical and light microscopy analysis. Food Chem. Toxicol.2007; 45, 2499-2505.

32. Dua, R., Gill, K.D., Effect of aluminium phosphide exposure on kinetic properties of cytochrome oxidase and mitochondrial energy metabolism in ratbrain. Biochim. Biophys. Acta.2004; 1674, 4-11.

33. Ward, R.J., Zhang, Y., Crichton, R.R., Aluminium toxicity and iron homeostasis.J. Inorg. Biochem.2001; 87, 9-14.

34 Sharma, P., Ahmad, S.Z., Kumar, A., Islam, F., Mishra, K.P. Role of combined administration of tiron and glutathione against aluminum-induced oxidative stress in rat brain. J. Trace Elem. Med. Biol.2007; 21, 63-70.

35 Shati, A.A., Elsaid, F.G., Hafez, E.E. Biochemical and molecular aspects of aluminium chloride-induced neurotoxicity in mice and the protective role of Crocus sativus L. extraction and honey syrup. Neuroscience.2011; $175,66-74$. 